\title{
Final Report of Research Conducted For DE-AI02-08ER64546
}

Period Summarized: January 1, 2010 - December 31, 2011

Principal Investigator: Patrick Minnis, NASA Langley Research Center

Since our last report covering the 2009 period, we published four papers that were accepted during the previous reporting period (F1-F4) and revised and published a fifth one (F5). Our efforts to intercalibrate selected channels on several polar orbiting and geostationary satellite imagers, which are funded in part by ASR, resulted in methods that were accepted as part of the international Global Space-based Intercalibration System (GSICS) calibration algorithms. (F9). We developed a new empirical method for correcting the spectral differences between comparable channels on various imagers that will be used to correct the calibrations of the satellite data used for ARM (F12).

We documented our cloud retrievals for the VAMOS Ocean-Cloud-Atmosphere-Land Study Regional Experiment (VOCALS-Rex; ARM participated with an AAF contribution) in context of the entire experiment (F7). We used our VOCALS satellite data along with the aircraft measurements to better understand the relationships between aerosols and liquid water path in marine stratus clouds (F6, F10, R16).

We continued or efforts to validate and improve the satellite cloud retrievals for ARM and using ARM data to validate retrievals for other purposes. Retrievals from MODIS and geostationary satellites were validated using ARM data taken at the SGP (F2, F8; R6, R7, R10, R12, R16, R31, R32) the Pt. Reyes AMF site (F8), the China AMF site (R17, R23), the NSA facility (R21, R26, R30, R33), the Azores AMF (R8), and the airborne facility during SPARTICUS/MACPEX (R29). Uncertainties in the algorithms used to produce ARM top-of-atmosphere radiative fluxes and cloud properties were also examined using comparisons with other surface and satellite data, (R1, R2, R3, R4, R5, R9, R11, R20, R22) as well as with ship data during CALNEX and CARES (R24). The cloud detection and retrieval algorithms were improved by instituting a clear-sky reflectance updating scheme (R14) that will affect the entire wide range of satellite-based cloud properties for ARM (R19), by introducing new cloud thickness, better ozone absorption computations, and reflectance models based on new ice crystal shapes (R8). A new parameterization was developed to obtain estimates of the 4-D structure of clouds over the SGP domain from passive satellite retrievals to complement the limited radar-based 4-D structure from the Central Facility radar (R4, R5, R18). ARM radar and Langley satellite cloud products were combined (R27) to provide a more accurate characterization of anvil cloud properties (R12) and the radiation budget of deep convective systems (F11). The results were used to improve satellite estimates of precipitation (R24, R26).

The cloud and radiation products, as well as the publications, are accessible through our web page (http://www-angler.larc.nasa.gov/).

Peer-reviewed Publications

\section{Publications \& Presentations}

F1. Chang, F.-L., P. Minnis, B. Lin, M. Khaiyer, R. Palikonda, and D. Spangenberg, 2010: A modified method for inferring cloud top height using GOES-12 imager 10.7- and 13.3- $\mu \mathrm{m}$ data. J. Geophys. Res., 115, D06208, doi:10.1029/2009JD012304. 
F2. Xi, B., X. Dong, P. Minnis, and M. M. Khaiyer, 2010: A 10-year climatology of cloud cover and vertical distribution derived from both surface and GOES observations over the DOE ARM SGP site. J. Geophys. Res., 115, D12124, doi:10.1029/2009JD012800.

F3. Chang, F.-L., P. Minnis, J. K. Ayers, M. J. McGill, R. Palikonda, D. A. Spangenberg, W. L. Smith, Jr., and C. R. Yost, 2010: Evaluation of satellite-based upper-troposphere cloud-top height retrievals in multilayer cloud conditions during TC4. J. Geophys. Res., D00J05, 115, doi:10.1029/2009JD012800.

F4. Bedka, K. M. and P. Minnis, 2010: GOES-12 observations of convective storm variability and evolution during the TC4 field program. J. Geophys. Res., 115, D00J13, doi:10.1029/2009JD013227.

F5. Kennedy, A. D., X. Dong, B. Xi, P. Minnis, A. D. DelGenio, A. B. Wolf, and M. M. Khaiyer, 2010: Evaluation of the NASA GISS Single Column Model simulated clouds using combined surface and satellite observations. J. Climate, 23, 5175-5192.

F6. Zheng, X., B. Albrecht, P. Minnis, K. Ayers, and H. Jonson, 2010: Observed aerosol and liquid water path relationships in marine stratocumulus. Geophys. Res. Lett., 37, L17803, doi:10.1029/2010GL044095.

F7. Wood, R., C. S. Bretherton, C. R. Mechoso, R. A. Weller, B. Huebert, F. Straneo, B. Albrecht, H. Coe, G. Allen, G. Vaughan, P. Daum, C. Fairall, D. Chand, L. Gallardo Klenner, R. Garreaud, C. Grados Quispe, D. S. Covert, T. S. Bates, R. Krejci, L. M. Russell, S. deSzoeke, A. Brewer, S. E. Yuter, A. Chaigneau, T. Toniazzo, P. Minnis, R. Palikonda, S. J. Abel, W. Brown, S. Williams, J. Fochesatto, and J. Brioude, 2010: The VAMOS Ocean-Cloud-Atmosphere-Land Study Regional Experiment (VOCALS-Rex): Goals, platforms, and field operations. Atmos. Chem. Phys., 11, 627-654, doi:10.5194/acp-11-627-2011.

F8. Minnis, P., S. Sun-Mack, Y. Chen, M. M. Khaiyer, Y. Yi, J. K. Ayers, R. R. Brown, X. Dong, S. C. Gibson, P. W. Heck, B. Lin, M. L. Nordeen, L. Nguyen, R. Palikonda, W. L. Smith, Jr., D. A. Spangenberg, Q. Z. Trepte, and B. Xi, 2011: CERES Edition-2 cloud property retrievals using TRMM VIRS and Terra and Aqua MODIS data, Part II: Examples of average results and comparisons with other data. IEEE Trans. Geosci. Remote Sens., 49, 11, 4401-4430.

F9. Goldberg, M., G. Ohring, J. Butler, C. Cao, R. Datla, D. Doelling, V. Gärtner, T. Hewison, B. Iacovazzi, D. Kim, T. Kurino, J. Lafeuille, P. Minnis, D. Renaut, J. Schmetz, D. Tobin, L. Wang, F. Weng, X. Wu, F. Yu, P. Zhang, and T. Zhu, 2011: The Global Space-based InterCalibration System (GSICS). Bull. Am. Meteorol. Soc., 92 (4), 467-475.

F10. Zheng, X., B. Albrecht, H. Jonson, D. Khelif, G. Feingold, P. Minnis, K. Ayers, S. Donaher, D. Rossiter, J. Ruiz-Plancarte, and S. Sun-Mack, 2011: Observations of the boundary layer, cloud, and aerosol variability in the southeast Pacific coastal marine stratocumulus during VOCALS-Rex. Atmos. Chem. Phys., 11, 9943-9959.

F11. Feng, Z., X. Dong, B. Xi, C. Schumacher, P. Minnis, and M. Khaiyer, 2011: TOA radiation budget of convective core/stratiform rain and anvil deep convective systems. J. Geophys. Res., 116, D23202, doi:10.1029/2011JD016451.

F12. Doelling, D. R., C. Lukashin, P. Minnis, B. Scarino, and D. Morstad, 2011: Spectral reflectance corrections for satellite intercalibrations using SCIAMACHY data. Geosci. Remote Sens. Lett., 9, 119-123, doi: 10.1109/LGRS.2011.2161751. 


\section{Conference and Meeting Papers and Presentations}

R1. Boeke, R., P. Minnis, J. K. Ayers, P.W. Heck, R. Palikonda, and R.F.Arduini, 2010: Angular dependencies of GOES-derived cloud properties over the continental United States. Proc. AMS $13^{\text {th }}$ Conf. Atmos. Rad. and Cloud Phys., Portland, OR, June 27 - July 2, CD-ROM, JP1.3.

R2. Khaiyer, M. M., P. Minnis, D. R. Doelling, M. L. Nordeen, R. Palikonda, D. A. Rutan, and Y. Yi, 2010: Improved TOA broadband shortwave and longwave fluxes derived from satellites over the Tropical Western Pacific. Proc. AMS $13^{\text {th }}$ Conf. Atmos. Rad., Portland, OR, June $27-$ July 2, P1.16.

R3. Chang, F.-L., P. Minnis, S. Sun-Mack, L. Nyugen, and Yan Chen, 2010: On the satellite determination of multi-layered multi-phase cloud properties. Proc. AMS $13^{\text {th }}$ Conf. Atmos. Rad. and Cloud Phys., Portland, OR, June 27 - July 2, JP1.10.

R4. Smith, W. L., Jr., P. Minnis, S. G. Benjamin, and S. S. Weygandt, 2010: 4-D water content fields derived from operational satellite data. Proc. IEEE 2010 Intl. Geosci. and Remote Sens. Symp., Honolulu, HI, July 25-30, DVD-ROM, pp. 308-311.

R5. Smith, W., P. Minnis, M. Khaiyer, R. Palikonda, D. Spangenberg, Y. Yi, and K. Bedka, 2010: A 4D cloud water content product derived from operational satellite data for ARM. $1^{s t}$ Atmospheric System Research Sci. Team Mtg., Bethesda, MD, Mar. 15-19.

R6. Bedka, S., P. Minnis, M. Khaiyer, and P. Heck, 2010: A comparison of GOES cloud optical property retrievals with ground and satellite-based reference data from SGP. $1^{\text {st }}$ Atmospheric System Research Sci. Team Mtg., Bethesda, MD, Mar. 15-19.

R7. Feng, Z., X. Dong, B. Xi, and P. Minnis, 2010: An evaluation of GOES microphysical property retrievals at anvil regions of deep convection by using MMCR and NEXRAD. $1^{s t}$ Atmospheric System Research Sci. Team Mtg., Bethesda, MD, Mar. 15-19.

R8. Minnis, P., W. Smith, J. Ayers, F.-L. Chang, G. Hong, M. Khaiyer, R. Palikonda, D. Spangenberg, H. Yi, and C. Yost, 2010: Improvements in characterizing ARM cloud and radiation fields using satellite data. $1^{\text {st }}$ Atmospheric System Research Sci. Team Mtg., Bethesda, MD, Mar. 15-19.

R9. Khaiyer, M., P. Minnis, D. Doelling, M. Nordeen, R. Palikonda, H. Yi, and D. Rutan, 2010: Validation of improved TOA shortwave and longwave broadband fluxes over the ARM TWP domain. $1^{\text {st }}$ Atmospheric System Research Sci. Team Mtg., Bethesda, MD, Mar. 15-19.

R10. Dong, X., B. Xi, K. Giannecchini, P. Minnis, S. Sun-Mack, and Y. Chen, 2010: Validation of CERES-MODIS Arctic cloud properties using both ARM and CloudSat/CALIPSO observations. $13^{\text {th }}$ CERES-II Sci. Team Mtg., Apr. 27-29.

R11. Gultepe, I., P. Minnis, J. Reid, N. Shantz, D Spangenberg, and R. Palikonda, 2010: Use of satellite observations for remote sensing of fog/clouds, and nowcasting. $15^{\text {th }}$ CASI Astronautics Conf. (ASTRO), Toronto, Canada, May 4- 6.

R12. Feng, Z., X. Dong, B. Xi, and P. Minnis, 2010: An evaluation of GOES microphysical property retrievals at anvil regions of deep convection by using MMCR and NEXRAD. $1^{s t}$ Atmospheric System Research Sci. Team Mtg., Bethesda, MD, Mar. 15-19.

R13. Heck, P. W., P. Minnis, S. T. Bedka, R. Palikonda, Y. Yi, M. M. Khaiyer, and F.-L. Chang, 2010: Cloud property retrievals from satellite data using thermal wavelengths in daytime and nighttime. AMS $13^{\text {th }}$ Conf. Atmos. Rad. and Cloud Phys., Portland, OR, June 27 - July 2, JP1.25. 
R14. Palikonda, R., P. Minnis, M. L. Nordeen, D. A. Spangenberg, B. Shan, P. W. Heck, Q. Z. Trepte, and T. Chee, 2010: Improvements to cloud detection and optical properties over snow background from geostationary satellite data. AMS $13^{\text {th }}$ Conf. Atmos. Rad. and Cloud Phys., Portland, OR, June 27 - July 2, JP1.34.

R15. Zeng, X. B. A. Albrecht, P. Minnis, and J. K. Ayers, 2010: Aerosol and liquid water path relationships in coastal non-drizzling marine stratocumulus over the subtropical southeastern Pacific. AMS $13^{\text {th }}$ Conf. Cloud Phys., Portland, OR, June 27 - July 2, P2.41.

R16. Xi, B., X. Dong, P. Minnis, and M. Khaiyer, 2010: A 10-year climatology of cloud fraction and vertical distribution derived from both surface and GOES observations over the DOE ARM SGP Site. AMS $13^{\text {th }}$ Conf. Atmos. Rad. and Cloud Phys., Portland, OR, June 27 - July 2, JP1.7.

R17. Dong, X., B. Xi, Y. Qiu, and P. Minnis, 2010: Validation of CERES ST retrieved MODIS cloud properties using DOE AMF-China and CloudSat observations. Earth Radiation Budget Workshop 2010, Paris, France, Sept. 13-16.

R18. Smith, W. L., Jr., P. Minnis, R. Palikonda, D. A. Spangenberg, and Y. Yi, 2010: A technique to infer cloud water content profiles from meteorological satellites. 2010 EUMETSAT Satellite Conference, Cordoba, Spain, September 20-24.

R19. Palikonda, R., P. Minnis, D. A. Spangenberg, T. L. Chee, B. Shan, and W. L. Smith, Jr., 2010: LaRC real-time satellite-derived cloud products, application and limitation. $A M S 17^{\text {th }}$ Conf. Satellite Meteorology \& Oceanography, Annapolis, MD, Sept. 27-30, P9.15.

R20. Khaiyer, M. M., P. Minnis, D. R. Doelling, M. L. Nordeen, R. Palikonda, D. Rutan, and Y. Yi, 2010: Validation of broadband shortwave and longwave fluxes derived from MTSAT over the Tropical Western Pacific. AMS $17^{\text {th }}$ Conf. Satellite Meteorology \& Oceanography, Annapolis, MD, Sept. 27-30, P4.9.

R21. Minnis, P. W. L. Smith, Jr., S. Sun-Mack, Y. Chen, D. A. Spangenberg, R. Palikonda, and R. F. Arduini, 2010: Retrieving cloud properties over snow and ice surfaces. $3^{\text {rd }}$ Intl. Symp. Recent Advances in Quantitative Remote Sens., Valencia, Spain, September 27-October 1, S3.1.

R22. Boeke, R., P. Minnis, P. W. Heck, R. Palikonda, and R. F. Arduini, 2010: The effect of partial cloudiness on quantifying angular biases in GOES cloud property retrievals. $2010 \mathrm{AGU}$ Fall Mtg., San Francisco, CA, December 13-17, A13A-0176.

R23. Qin, Y., X. Dong, B. Xi, and P. Minnis, 2010: Comparisons of CERES-MODIS and CloudSat/CALIPSO cloud properties with DOE ARM AMF measurements at Shouxian, China. 2010 AGU Fall Mtg., San Francisco, CA, December 13-17, A13A-0178.

R24. McBride, P. J., S. Schmidt, P. Pilewskie, S. Lance, P. Minnis, K. M. Bedka, and D. E. Wolfe, 2010: Cloud property retrievals from surface spectral transmittance and airborne spectral reflectance: comparisons with satellite, microwave, and in-situ observations during CalNex. 2010 AGU Fall Mtg., San Francisco, CA, December 13-17, A22B-05.

R25. Feng, Z., X. Dong, B. Xi, P. Minnis, M. Khaiyer, and A. Aghakouchak, 2010: Improving satellite-based instantaneous precipitation estimate using integration of ground radar and satellite dataset. 2010 AGU Fall Mtg., San Francisco, CA, December 13-17, H24D-05.

R26. Spangenberg, D., P. Minnis, R. Palikonda, F. Chang, and M. Shupe, 2010: Using MODIS data to detect the presence of ice crystals in and above supercooled liquid water clouds over the Arctic. 2010 AGU Fall Mtg., San Francisco, CA, December 13-17, A43B-0232. 
R27. Feng, Z., X. Dong, B. Xi, P. Minnis, and M. Khaiyer, 2011: Integration of ground radar and satellite dataset for studying cloud and radiative property of deep convective systems. $91^{\text {st }}$ Amer. Meteorol. Soc. Ann. Mtg., Seattle, WA, January 24-27.

R28. Feng, Z., X. Dong, B. Xi, P. Minnis, and M. Khaiyer, 2011: Improving GOES derived rain areal coverage estimate by using a hybrid WSR- 88 and GOES classification for deep convective systems. $91^{\text {st }}$ Amer. Meteorol. Soc. Ann. Mtg., Seattle, WA, January 24-27.

R29. Yost, C. R., P. Minnis, J. K. Ayers, R. Palikonda, D. Spangenberg, F.-L. Chang, S. SunMack, P. Heck, and P. Lawson, 2011: Evaluation of in situ and satellite-derived cirrus microphysical properties during SPARTICUS. 2011 Atmos. Sci. Res. Sci. Team Mtg., San Antonio, TX, March 28 - April 1.

R30. Dong, X., K. Giannechini, B. Xi, and P. Minnis, 2011: Validation of CERES-MODIS cloud properties over the Arctic using ARM and CloudSat/CALIPSO observations. CERES Sci. Team Mtg., Newport News, VA, April 26-28.

R31. Heck, P. W., P. Minnis, S. T. Bedka, and C. R. Yost, 2011: Validation of GOES-R nighttime cloud and optical properties. 2011 NOAA STAR GOES-R AWG Ann. Rev., Ft. Collins, CO, June 14-16.

R32. Chang, F.-L., P. Minnis, and S. Sun-Mack, 2011: Towards multilayered cloud detection and retrieval using passive satellite data. Asia Oceania Geosci. Soc. (AOGS) $8^{\text {th }}$ Ann. Mtg., Taipei, Taiwan, August 8-12.

R33. Giannecchini, K., X. Dong, B. Xi, P. Minnis, and S. Kato, 2011: Validation of CERESMODIS Arctic cloud properties using CloudSat/CALIPSO and ARM NSA observations. $A G U$ Fall Mtg 2011, 5-9 December, San Francisco, CA, A31C-0084. 